Received: 30 April 2018

Accepted: 20 December 2018

Published online: 07 February 2019
NTIFIC REP

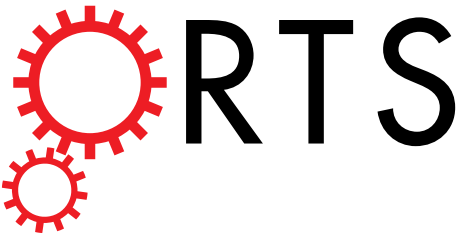

\section{OPEN Greenhouse and field evaluation of a novel HPPD-inhibiting herbicide, QYM201, for weed control in wheat}

\author{
Fengwen Zhang, Shuang Bai, Hengzhi Wang, Weitang Liu \& Jinxin Wang
}

OYM201, 1-(2-chloro-3-(3-cyclopropyl-5-hydroxy-1-methyl-1H-pyrazole-4-carbonyl)-6(trifluoromethyl)phenyl)piperidin-2-one), is a newly developed HPPD- (4-hydroxyphenylpyruvate dioxygenase; EC 1.13.11.27) inhibiting herbicide for weed control. Experiments were carried out to determine the effect of QYM201 on weeds and its safety for wheat in the glasshouse and field. The results indicated that at doses of 90 and $135 \mathrm{~g}$ active ingredient (a.i.) ha ${ }^{-1}$ OYM201 was highly effective against both grass and broadleaf weeds, such as Alopecurus aequalis Sobol., Alopecurus japonicus Steud, and Capsella bursa-pastoris Medic. In a wheat hybrid tolerance experiment, OYM201 showed a high level of safety for most of the 17 tested wheat hybrids, and the SI values reached $\geq 5.7$ in the selectivity index study. To determine application rules for QYM201, field experiments were conducted in 2016 and 2017. During this time, 90 to $270 \mathrm{~g}$ a.i. ha ${ }^{-1}$ post-emergence herbicide application (POST) was sufficient to supply satisfactory all-season control of Alopecurus aequalis Sobol., Descurainia sophia [L.] Schur., and Malachium aquaticum (L.) Fires. No damage to wheat plants was observed. In order to increase wheat yield and deliver effective weed control, a dosage of 90 to $180 \mathrm{~g} \mathrm{a.i.} \mathrm{ha}^{-1}$ is suggested. In conclusion, the herbicide OYM201 is safe to use in wheat fields to control winter weeds.

Winter wheat (Triticum aestivum L.) is the second most widely grown food crop in China, with a planting area of 24.1 million hectares and a production of 130.2 million tons in $2015^{1}$. Severe wheat yield losses can be caused by weeds with potential reductions up to $15 \%{ }^{2,3}$. Alopecurus japonicus Steud., Beckmannia syzigachne [Steud.] Fern., Alopecurus aequalis Sobol., Vicia sativa L, Capsella bursa-pastoris Medic., Descurainia sophia [L.] Schur., and Avena fatua $\mathrm{L}$ are examples of common troublesome weeds in winter wheat fields ${ }^{4}$. Substantial yield reduction takes place when these weeds are not fully controlled.

Herbicides have been used for weed control in China since the early $1990 \mathrm{~s}^{5}$; nowadays, chemical weed control still has an important role in producing high-yielding crops ${ }^{6}$. Herbicides with different modes of action can kill $90 \%$ to $99 \%$ of target weeds and are the most useful means of weed control developed ${ }^{7-9}$; however, this is not problem free. One case study reveals that more than 252 weed species have developed resistance to 23 different herbicides worldwide ${ }^{10}$. In China, almost 30 weed species have developed resistance to nearly 50 herbicides with more than 10 different sites of action so far ${ }^{11}$. Most recently, Zhu et al. reported that at least 12 weed species have been confirmed resistant to the main herbicides commonly used in wheat fields ${ }^{11}$. Specifically, in Jiangsu and Anhui provinces of China, A. japonicus, a widespread troublesome weed, has developed resistance to about 20 herbicides. These 20 herbicides include not only Acetyl-CoA carboxylase (ACCase) herbicides such as fenoxaprop-P-ethyl, pinoxaden, clodinafop-propargyl, and sethoxydim, but also include Acetolactate synthase (ALS) herbicides: pyribenzoxim, imazapic, imsulfuron, sulfosulfuron, penoxsulam, and pyroxsulam ${ }^{12}$. Another problem is that some herbicides have a narrow weed spectrum and occasionally can cause damage to wheat plants; for example, Fluroxypyr is effective in controlling some broadleaf weeds but is ineffective against C. bursa-pastoris (L.) Medic. Mesosulfuron plus iodosulfuron can kill most weed species but sometimes damage wheat plants. Hence, the widespread use of Mesosulfuron and iodosulfuron has been limited in China. In another example, 2, 4-D butyl ester has become a commonly used herbicide in wheat fields for controlling broadleaf weeds in China, but it can cause damage to broadleaf crops due to spray drift and volatilization; this is particularly relevant with cotton ${ }^{13,14}$. In addition to the problems described above, extensive use of herbicides can also

Key Laboratory of Pesticide Toxicology and Application Technique, College of Plant Protection, Shandong Agricultural University, Tai'an, 271018, China. Correspondence and requests for materials should be addressed to W.L. (email: liuwt@sdau.edu.cn) or J.W. (email: wangjx@sdau.edu.cn) 


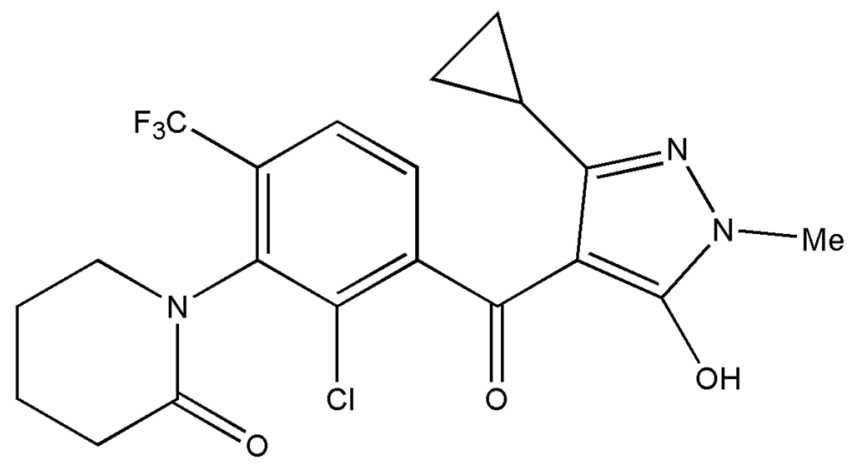

Figure 1. Chemical structure of the herbicide QYM201 used in this study.

lead to an accelerated succession of weed communities. Therefore, herbicides with a new site of action, that have broad-spectrum weed control, high efficacy, and are safe to use on wheat are urgently needed.

QYM201, $\left(\mathrm{C}_{20} \mathrm{H}_{19} \mathrm{ClF}_{3} \mathrm{~N}_{3} \mathrm{O}_{3}\right.$, 1-(2-chloro-3-(3-cyclopropyl-5-hydroxy-1-methyl-1H-pyrazole-4-carbonyl)-6(trifluoromethyl)phenyl)piperidin-2-one; Fig. 1), is a novel HPPD-inhibiting herbicide that was developed by Qingdao Kingagroot Chemicals Co., Ltd. in $2011^{15}$. 4-hydroxyphenylpyruvate dioxygenase (HPPD) is a class of $\alpha$-keto acid-dependent non-heme iron (II) oxygenases which can be found in mammals, plants, and most microbes. HPPD catalyzes oxygenation of 4-hydroxyphenylpyruvate (HPP) to generate homogentisate (HG) ${ }^{16-19}$. The biosynthesis of prenylquinone and tocopherols is prevented once HPPD is inhibited in plants, which leads to a decrease in carotenoid biosynthesis, blocking of photosynthetic electron transfer chains, and photooxidation of chloroplast $^{20,21}$. Consequently, treated plants become bleached to death ${ }^{21}$. Therefore HPPD is selected as a target for herbicide development. To our knowledge, HPPD inhibitors have not been used in wheat fields anywhere in the world. Therefore, we suggest that QYM201 is a potentially beneficial herbicide for weed control, especially for resistant and harmful weeds in wheat fields.

In order to determine the spectrum of weed control, the safety to different wheat hybrids, and the selectivity of QYM201 among 3 commonly planted wheat hybrids and 4 common weeds, experiments were carried out in the greenhouse. In addition, field experiments were conducted to determine the effect of QYM201 on weed control in winter wheat fields with different rates of 6\% QYM201 oil dispersion (OD) during the 2015-2016 and 2016-2017 growing seasons in Shandong province.

\section{Results}

Greenhouse experiments. Effectiveness of weed control. At all rates of application, QYM201 was effective on many of the tested weed species including grass weeds and broadleaf weeds. Treated weeds exhibited symptoms of bleach injury at 5 days after treatment (DAT), eventually undergoing necrosis and death at 20 DAT. At the dosage of $90 \mathrm{~g}$ a.i. ha ${ }^{-1}$, QYM201 was highly effective against 3 of the treated weeds, and dry weight inhibition of $A$. aequalis, M. aquaticum, and D. sophia. were up to $93 \%, 91 \%$, and $92 \%$, respectively. Meanwhile dry weight inhibition of A. japonicus, and L. arvense were $86 \%$ and $87 \%$, respectively. Weed injury increased according to application rate - higher rates leading to greater injury. At a dosage of $135 \mathrm{~g}$ a.i. ha ${ }^{-1}, 8$ of the treated weeds were controlled by QYM201, with dry weight reductions ranging from $91 \%$ to $95 \%$ these weeds included A. aequalis, A. japonicus, C. bursa-pastoris, M. aquaticum, V. didyma, P. kengiana, L. arvense, and D. sophia (Table 1). However, even at high doses some weed species, such as L. multiflorum, B. japonicus, A. squarrosa, and E. helioscopia, showed only slight sensitivity to QYM201 with dry weight reductions of 21\%,23\%, 20\%, and 19\%, respectively.

Wheat hybrid tolerance. QYM201 was safe for most of the treated wheat in the greenhouse experiment. When treated at $360 \mathrm{~g}$ a.i. ha ${ }^{-1}$, most of the tested wheat hybrids were tolerant to QYM201 with reductions of $<7 \%$ and herbicide damage $<20 \%$ (Table 2). However, Huamai 5, Yangfumai 4, and Yangmai 158 were sensitive to QYM201, showing dry weight reductions of $13 \%, 12 \%$, and 17\%, respectively. The damage caused by QYM201 to these 3 hybrids ranging from $12 \%$ to $17 \%$ (Table 2). Wheat hybrids Zhengmai 10, Hengguan 35, Haomai 1, and Xinong 979 became sensitive to QYM201 with dry weights inhibited by beyond 10\%, while crop injury caused by the herbicide was up to $28 \%$ at a dose of $540 \mathrm{~g}$ a.i. ha ${ }^{-1}$ (Table 2). Meanwhile, there were obvious differences in sensitivity to QYM201 among the wheat hybrids. Most hybrids showed little if any reaction to the herbicide; Shannong 22, Jinan 17, Shannong 19, Zhengmai 9023, Yannong 19, Ningmai 24, Jimai 22, Liangxing 66, and Tainong 18 exhibited no obvious damage, and reductions in plant dry weights were $<10 \%$, with herbicide damage $<20 \%$. At the beginning of the treatment, some wheat plants showed some symptoms of whitening at 5 DAT, but subsequently all of them regained a normal appearance at approximately 12 DAT (Table 2).

Selectivity index (SI). In view of the wheat hybrid tolerance results, a dose-response study was performed to determine the SI values between 3 wheat hybrids (JM 22, LX 66, TN 18) and 4 weed species (A. aequalis, A. japonicus, C. bursa-pastoris, and M. aquaticum). $\mathrm{GR}_{50}$ values of the 3 wheat hybrids were 4856.7, 2469.2, and 6114 while the values of the 4 weed species were $28.1,58.9,40.5$, and 24.9 , respectively (Table 3 ). The high $\mathrm{GR}_{50}$ values clearly indicated that QYM201 was safe for the 3 tested wheat hybrids and that the 4 weed species were also effectively controlled (Table 3 ). In addition, experimental results showed that A. aequalis and M. aquaticum 


\begin{tabular}{|c|c|c|c|c|}
\hline \multirow[b]{3}{*}{ Trial weeds } & \multicolumn{2}{|c|}{$\begin{array}{l}\text { Dry weight inhibition } \\
(\mathrm{SE})^{\mathrm{a}} \mathrm{g} \text { a.i. } \mathrm{ha}^{-1}\end{array}$} & \multirow[b]{3}{*}{ F-statistic } & \multirow[b]{3}{*}{ P-value } \\
\hline & 90 & 135 & & \\
\hline & \multicolumn{2}{|l|}{$\%$} & & \\
\hline Alopecurus aequalis Sobol. (Water foxtail) & $93(0.4)$ & $94(0.3) \mathrm{NS}$ & 2.63 & 0.247 \\
\hline Alopecurus japonicus Steud. (Japanese foxtail) & $86(0.2)$ & $91(0.5) * *$ & 485.04 & 0.002 \\
\hline Capsella bursa-pastoris (L.) Medic (Shepherd's purse) & $85(0.1)$ & $91(0.3) * *$ & 462.36 & 0.002 \\
\hline Malachium aquaticum (L.) Fires (Crickweed) & $91(0.1)$ & $94(0.4)^{*}$ & 45.14 & 0.021 \\
\hline Veronica didyma Tenore (Speedwell) & $86(0.3)$ & $91(0.4)^{*}$ & 34.26 & 0.028 \\
\hline Becmannia syzigachne (Steud.) Fern. (American slough grass) & $80(0.2)$ & $83(0.0) * *$ & 181.21 & 0.006 \\
\hline Pseudosclerochloa kengiana (Ohwi) (Hardgrass) & $85(0.1)$ & $91(0.6)^{*}$ & 46.13 & 0.021 \\
\hline Poa annua L. (Annual bluegrass) & $12(0.7)$ & $27(0.7)^{*}$ & 60.32 & 0.016 \\
\hline Lithospermum arvense L. (Corn gromwell) & $87(0.3)$ & $93(0.4)^{*}$ & 80.11 & 0.012 \\
\hline Descurainia sophia (L.) Schur. (Flixweed) & $92(0.0)$ & $95(0.2) * *$ & 646.02 & 0.002 \\
\hline Geranium sibiricum L. (Carolina cranesbill herb) & $45(0.6)$ & $52(0.8) \mathrm{NS}$ & 10.19 & 0.086 \\
\hline Galium aparine L. var. tenerum (Gren. et Godr.) Rcbb. (Catchweed) & $27(0.2)$ & $36(0.6) *$ & 52.92 & 0.018 \\
\hline Lolium multiflorum Lam. (Italian ryegrass) & $13(0.1)$ & $21(1.0)^{*}$ & 30.74 & 0.031 \\
\hline Bromus japonicus Thunb. (Japanese brome) & $19(0.2)$ & $23(0.7)^{*}$ & 28.96 & 0.033 \\
\hline Aegilops squarrosa L. (Triticum tauschii) & $14(0.1)$ & $20(1.0)^{*}$ & 26.49 & 0.036 \\
\hline Avena fatua L. (Wild oat) & $47(0.7)$ & $61(1.0)^{* *}$ & 531.37 & 0.002 \\
\hline Vicia sativa L. (Vetch) & $44(0.7)$ & $53(1.2) \mathrm{NS}$ & 6.74 & 0.122 \\
\hline Euphorbia helioscopia L. (Sun spurge) & $14(1.0)$ & $19(1.4)^{* *}$ & 160.45 & 0.006 \\
\hline
\end{tabular}

Table 1. Dry weight inhibitions of trial weeds treated with QYM201 relative to the non-treated control in a greenhouse study 28 days after treatment (DAT). a Significant differences between the 2 rates at the 0.05 level according to Fisher's protected LSD test. *Significant at $\mathrm{P}<0.05$; **significant at $\mathrm{P}<0.01$; ***significant at $\mathrm{P}<0.001 ;$ NS, not significant.

were more sensitive to QYM201 under post emergence herbicide applications (POST) than A. japonicus and C. bursa-pastoris (Table 3, Fig. 2). SI values from Table 3 indicate that QYM201 was safe for JM 22, LX 66, and TN 18 against weeds tested in this study with values ranging from 5.7 to 16.6 .

Field experiment. Throughout the 2 years of field experiments, QYM201 performed with good efficacy against $A$. aequalis, D. sophia, and M. aquaticum (Table 4). The 3 weed species began turning white and stopped growing within 15 days after treatment (DAT). When treated at doses of 90-270 g a.i. ha ${ }^{-1}$, all weed densities decreased; moreover, control over A. aequalis, D. sophia, and M. aquaticum to levels of $90.6 \%$ to $100 \%$ was achieved in 45 DAT. Just as speculated, fenoxapro-P-ethyl had almost no effect on D. sophia and M. aquaticum, and tribenuron-methyl did not affect A. aequalis. QYM201 provided biomass reductions of $100 \%$ in 2016 and $99.6 \%$ in 2017 for $A$. aequalis at a dosage of $270 \mathrm{~g}$ a.i. ha ${ }^{-1}$. It supplied a high biomass reduction (>90\%) even at the lower rate of $90 \mathrm{~g}$ a.i. ha ${ }^{-1}$. Furthermore, no obvious damage to the wheat crop was observed at all tested rates during 2016 and 2017 (Table 5). The grain yield of wheat increased with increasing rates of QYM201 from 90 to $270 \mathrm{~g}$ a.i. $\mathrm{ha}^{-1}$ (Table 5). Specifically, in the field experiments of 2017, a 19\% yield increase was achieved by increasing the rate from 0 to $270 \mathrm{~g}$ a.i. ha ${ }^{-1}$. The yield in hand-weeded plots could be reduced by about $20 \%$ in two years, and none of the herbicide treatments led to superior grain yields compared with hand-weeded plots (Table 5).

\section{Discussion}

The chemical structure of the herbicide QYM201 (Fig. 1), is similar to that of topramezone, which is a typical HPPD-inhibitor ${ }^{22}$. Furthermore, weeds or crops that have been treated with QYM201 present with typical HPPD inhibitor injury characteristics. Thus QYM201 is suggested to be a novel member of the group of chemicals that inhibits 4-hydroxyphenylpyruvate dioxygenase ${ }^{15}$.

The greenhouse bioassay results indicated that the weed control spectrum of QYM201 was broader than that of most commonly used herbicides in wheat fields; at all rates of application, QYM201 was able to control both grass weeds and broadleaf weeds. Post emergence applications of herbicides such as fluroxypyr and tribenuron-methyl are highly efficient against a large number of broadleaf weeds but provide only limited control for grass weeds ${ }^{23,24}$. Whereas fenoxaprop-P-ethyl and mesosulfuron-methyl are sufficiently effective against many grass weeds, they are not effective for broadleaf weeds ${ }^{25}$. The ability of QYM201 to control both grass and broadleaf weeds may make it a preferred choice over any other ordinary herbicides for weed control in wheat fields. Importantly, we found that QYM201 was highly effective in its control of A. aequalis and A. japonicus, which are the most harmful weeds to wheat yield worldwide. The widespread application of herbicides has led to the rapid evolution of $A$. aequalis and $A$. japonicus herbicide tolerance throughout the world. In some areas of China, $A$. aequalis has developed resistance to ALS inhibitors ${ }^{26,27}$, and/or ACCase inhibitors ${ }^{27,28}$, while A. japonicus has developed resistance to chlorsulfuron ${ }^{28,29}$, to fenoxaprop-P-ethyl ${ }^{30-32}$, to isoproturon ${ }^{30}$, and/or to pinoxaden ${ }^{31}$. Therefore, QYM201 will be helpful in controlling these resistant weeds. However, more attention should be given to preventing the 


\begin{tabular}{|c|c|c|c|c|c|c|c|c|}
\hline \multirow[b]{4}{*}{ Wheat hybrid } & \multirow{2}{*}{\multicolumn{2}{|c|}{\begin{tabular}{|l|} 
Dry weight inhibition $(\mathrm{SE})^{\mathrm{a}}$ \\
g a.i. $^{-1} \mathrm{ha}^{-1}$
\end{tabular}}} & \multirow[b]{4}{*}{ F-statistic } & \multirow[b]{4}{*}{ P-value } & \multirow{2}{*}{\multicolumn{2}{|c|}{\begin{tabular}{|l|} 
Wheat injury rating $(\mathrm{SE})^{\mathrm{a}, \mathrm{b}}$ \\
g a.i. $^{-1} \mathrm{~h}^{-1}$
\end{tabular}}} & \multirow[b]{4}{*}{ F-statistic } & \multirow[b]{4}{*}{ P-value } \\
\hline & & & & & & & & \\
\hline & 360 & 540 & & & 360 & 540 & & \\
\hline & \multicolumn{2}{|l|}{$\%$} & & & \multicolumn{2}{|l|}{\begin{tabular}{|l|}
$\%$ \\
\end{tabular}} & & \\
\hline Shannong 22 & $1(0.5)$ & 3 (1.9) NS & 2.34 & 0.266 & 0 & $0 \mathrm{NS}$ & $\mathrm{ND}^{\mathrm{c}}$ & ND \\
\hline Zhenmai 10 & $7(0.0)$ & $11(1.8) \mathrm{NS}$ & 4.84 & 0.159 & $12(1.8)$ & $42(0.6)^{* * *}$ & 106.21 & 0.009 \\
\hline Jinan 17 & $2(0.2)$ & $9(0.5)^{* *}$ & 168.83 & 0.006 & $4(0.8)$ & $23(0.9)^{* * * *}$ & 3172.33 & 0.000 \\
\hline Huamai 5 & $13(0.1)$ & $18(1.8) \mathrm{NS}$ & 5.31 & 0.148 & $34(2.4)$ & $48(0.9) \mathrm{NS}$ & 6.85 & 0.120 \\
\hline Shannong 19 & $1(0.5)$ & 4(1.2) NS & 10.00 & 0.087 & 0 & $0 \mathrm{NS}$ & ND & ND \\
\hline Jimai 17 & $2(1.5)$ & $10(1.2) \mathrm{NS}$ & 15.41 & 0.059 & $5(0.2)$ & $17(1.1)^{*}$ & 83.15 & 0.012 \\
\hline Yangfumai 4 & $12(0.3)$ & $14(0.1)^{* *}$ & 98.61 & 0.010 & $34(1.7)$ & $45(0.8)^{*}$ & 18.65 & 0.050 \\
\hline Hengguan 35 & $3(1.0)$ & $12(1.0) *$ & 26.12 & 0.036 & $10(0.9)$ & $28(1.2) * *$ & 1542.29 & 0.001 \\
\hline Zhengmai 9023 & $7(0.1)$ & $9(0.9) \mathrm{NS}$ & 2.29 & 0.270 & $7(1.0)$ & $18(0.7)^{* *}$ & 406.75 & 0.003 \\
\hline Yannong 19 & $2(0.4)$ & $5(0.6) \mathrm{NS}$ & 12.71 & 0.071 & 0 & $0 \mathrm{NS}$ & ND & ND \\
\hline Haomai 1 & $5(0.7)$ & $16(0.1)^{* *}$ & 321.92 & 0.003 & $10(0.2)$ & $32(1.0)^{* * *}$ & 366.57 & 0.003 \\
\hline Ningmai 24 & $0(1.2)$ & $5(1.7)^{* *}$ & 382.07 & 0.003 & $2(1.1)$ & $5(0.8) \mathrm{NS}$ & 4.99 & 0.155 \\
\hline Yangmai 158 & $17(0.2)$ & $21(0.9)^{*}$ & 21.29 & 0.044 & $35(1.4)$ & $53(0.5)^{*}$ & 29.50 & 0.032 \\
\hline Xinong 979 & $5(0.8)$ & $13(0.8)^{*}$ & 23.52 & 0.040 & $16(0.7)$ & $32(0.6)^{*}$ & 67.92 & 0.014 \\
\hline Jimai 22 & $1(1.8)$ & $4(1.6) * * *$ & 713.52 & 0.001 & $8(0.6)$ & $25(0.9)^{*}$ & 87.35 & 0.011 \\
\hline Liangxing 66 & $2(0.2)$ & $8(0.4)^{* *}$ & 179.89 & 0.006 & $12(0.7)$ & $27(0.5)^{* *}$ & 233.06 & 0.004 \\
\hline Tainong 18 & $3(0.4)$ & $6(0.7) \mathrm{NS}$ & 12.76 & 0.070 & $3(0.8)$ & $14(0.8) * * *$ & 3768.20 & 0.000 \\
\hline
\end{tabular}

Table 2. Dry weight inhibitions (\%) and visual injury ratings (\%) of trial wheat hybrids treated with QYM201 as a POST relative to the non-treated control in a greenhouse study 28 days after treatment (DAT). aSignificant differences between the 2 rates according to Fisher's protected LSD test. *Significant at $\mathrm{P}<0.05$; $* *$ significant at $\mathrm{P}<0.01$; ***significant at $\mathrm{P}<0.001$; NS, not significant. ${ }^{b}$ Injury rating scale: $0 \%=$ no injury, $0 \sim 30 \%=$ cotyledon and a few functional leaves showed bleaching in addition to newly-emerged leaves, $30 \sim 60 \%=$ cotyledon, minority of functional leaves and newly-emerged leaves presented bleaching, $60 \sim 100 \%=$ most plants showed sever whitening symptoms and some even showed necrosis, $100 \%=$ plant death. ${ }^{\mathrm{N} D}$, not determined.

\begin{tabular}{|c|c|c|c|c|c|c|}
\hline \multirow[b]{3}{*}{ Trial plants } & \multicolumn{3}{|c|}{ GR value $(\mathrm{SE})^{\mathrm{a}}$} & \multicolumn{3}{|l|}{$\mathrm{SI}^{\mathrm{b}}$} \\
\hline & $\mathbf{G R}_{10}$ & $\mathrm{GR}_{50}$ & $\mathbf{G R}_{\mathbf{9 0}}$ & \multirow[b]{2}{*}{ JM 22} & \multirow[b]{2}{*}{ LX 66} & \multirow[b]{2}{*}{ TN 18} \\
\hline & \multicolumn{3}{|l|}{ ga.i. ha-1 } & & & \\
\hline Jimai 22 & $930.4(18.9)$ & $4856.7(38.9)$ & $\mathrm{ND}^{\mathrm{c}}$ & ND & ND & ND \\
\hline Liangxing 66 & $784.4(12.8)$ & $2469.2(26.8)$ & ND & ND & ND & ND \\
\hline Tainong 18 & $1190.6(21.6)$ & $6114.0(41.6)$ & ND & ND & ND & ND \\
\hline Alopecurus aequalis & ND & $28.1(3.2)$ & $80.8(1.9)$ & 11.5 & 9.7 & 14.7 \\
\hline Alopecurus japonicus & ND & $58.9(2.7)$ & $115.0(2.6)$ & 8.1 & 6.8 & 10.4 \\
\hline Capsella bursa-pastoris & ND & $40.5(0.8)$ & $137.5(3.2)$ & 6.8 & 5.7 & 8.7 \\
\hline Malachium aquaticum & $\mathrm{ND}^{\mathrm{c}}$ & $24.9(1.4)$ & $71.5(1.1)$ & 13.0 & 11.0 & 16.6 \\
\hline
\end{tabular}

Table 3. The doses of QYM201 causing $10 \%$ and $50 \%$ reduction of wheat dry weight and $50 \%$ and $90 \%$ of weeds' dry matter, and the selectivity index (SI) values between 3 wheat hybrids and the 4 weed species 28 days after treatment (DAT) in greenhouse research. ${ }^{a} \mathrm{GR}$, inhibitory concentration. ${ }^{\mathrm{b}} \mathrm{SI}$, selectivity index values were calculated by equation $2 .{ }^{\mathrm{C}} \mathrm{ND}$, not determined.

development of resistance to QYM201, especially in A. aequalis or A. japonicus, by alternately using herbicides at different sites of action, promoting the diversity of crop cultivation, using biological controls, and the rational mixing of herbicides ${ }^{32}$. However, the efficacy of QYM201 on a greater number of weed species that occur in wheat fields needs to be tested before recommendation of its widespread application.

In crop safety experiments, under all tested application rates, QYM201 was safe for most of the 17 tested hybrid wheat varieties. These results strongly suggested that QYM201 is an excellent alternative herbicide for controlling weeds in wheat fields. Moreover, the SI values were identified for JM22, LX66, TN18, and 4 common weeds that occur in wheat fields. It is well known that herbicides are more selective between crops and weeds when the SI value is greater than $1.0^{33}$, and herbicides can be safely used in crops when the SI value increases over $2.0^{34}$. In this study, we found that QYM201 was safe for JM22, LX66, and TN18 against A. aequalis, A. japonicus, C. bursa-pastoris, and M. aquaticum when POST was applied, with SI values from 5.7 to 16.6. However, the safety of QYM201 for use on other wheat hybrids should be assessed in further experiments in view of the complex distribution of wheat hybrids throughout different areas of China. 


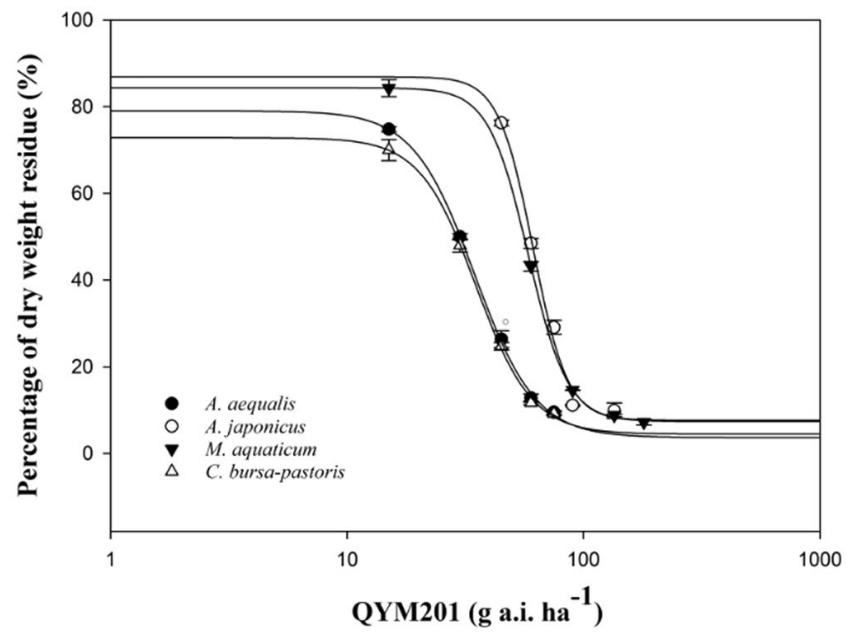

Figure 2. Percentage of dry weight residue of A. aequalis, A. japonicus, M. aquaticum, and C. bursa-pastoris as influenced by different doses of QYM201 at 28 days after treatment (DAT) in a greenhouse study. The regression lines were calculated using Equation 1.

\begin{tabular}{|c|c|c|c|c|c|c|c|}
\hline \multirow[b]{4}{*}{ Treatments } & \multirow{4}{*}{\begin{tabular}{|l} 
Dose \\
ga.i. ha \\
\end{tabular}} & \multicolumn{6}{|c|}{ Percent weed control ${ }^{a, b}$} \\
\hline & & \multicolumn{2}{|c|}{ Alopecurus aequalis } & \multicolumn{2}{|c|}{ Descurainia sophia } & \multicolumn{2}{|c|}{$\begin{array}{l}\text { Malachium } \\
\text { aquaticum }\end{array}$} \\
\hline & & 2016 & 2017 & 2016 & 2017 & 2016 & 2017 \\
\hline & & \multicolumn{6}{|l|}{$\%$} \\
\hline QYM201 & 90 & $91.7 \mathrm{c}$ & $90.6 \mathrm{~d}$ & $93.5 \mathrm{~d}$ & $91.9 \mathrm{~d}$ & $94.2 \mathrm{~b}$ & $94.6 \mathrm{~b}$ \\
\hline QYM201 & 135 & $94.7 \mathrm{~b}$ & $92.2 \mathrm{c}$ & $95.8 \mathrm{c}$ & $95.9 \mathrm{c}$ & $94.6 \mathrm{~b}$ & $95.0 \mathrm{~b}$ \\
\hline QYM201 & 180 & $99.4 \mathrm{a}$ & $96.3 \mathrm{~b}$ & $97.9 \mathrm{~b}$ & $96.6 \mathrm{~b}$ & $97.3 \mathrm{a}$ & $97.6 \mathrm{a}$ \\
\hline QYM201 & 270 & $100.0 \mathrm{a}$ & $99.6 \mathrm{a}$ & $99.9 \mathrm{a}$ & $98.5 \mathrm{a}$ & $98.9 \mathrm{a}$ & $97.8 \mathrm{a}$ \\
\hline Fenoxapro-P-ethyl & 50 & $88.3 \mathrm{~d}$ & $83.3 \mathrm{e}$ & - & - & - & - \\
\hline Tribenuron-methyl & 22.5 & - & - & $76.1 \mathrm{e}$ & $80.7 \mathrm{e}$ & $91.8 \mathrm{c}$ & $91.6 \mathrm{c}$ \\
\hline Hand-weeding & - & - & - & - & - & - & - \\
\hline Weedy control & - & - & - & - & - & - & - \\
\hline
\end{tabular}

Table 4. Visual estimates of percentage control of weeds under different POST rates of QYM201 at Taian,

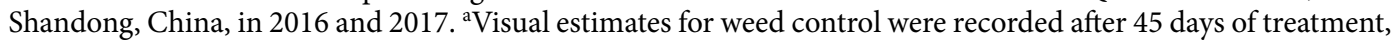
using a $0 \%$ (no weed control) to $100 \%$ (complete weed control) scale. ${ }^{\text {b }}$ The following different letters represent different significance at the $\mathrm{P}<0.05$ level according to Fisher's protected LSD test.

\begin{tabular}{|c|c|c|c|c|c|c|c|c|c|c|c|c|c|}
\hline \multirow[b]{4}{*}{ Treatments } & \multirow[b]{3}{*}{ Dose } & \multicolumn{8}{|c|}{ Crop injury ${ }^{\mathrm{a}, \mathrm{b}}$} & \multirow{2}{*}{\multicolumn{2}{|c|}{ Wheat yield ${ }^{b, c}$}} & \multirow{2}{*}{\multicolumn{2}{|c|}{$\begin{array}{l}\text { Yield growth } \\
\text { rate }^{c}\end{array}$}} \\
\hline & & \multicolumn{2}{|c|}{3 DAT } & \multicolumn{2}{|c|}{5 DAT } & \multicolumn{2}{|c|}{15 DAT } & \multicolumn{2}{|c|}{30 DAT } & & & & \\
\hline & & 2016 & 2017 & 2016 & 2017 & 2016 & 2017 & 2016 & 2017 & 2016 & 2017 & 2016 & 2017 \\
\hline & $\begin{array}{l}\text { ga.i. } \\
\text { ha }^{-1}\end{array}$ & \multicolumn{8}{|l|}{$\%$} & \multicolumn{2}{|l|}{$\mathrm{kg} \mathrm{ha}^{-1}$} & \multicolumn{2}{|l|}{$\%$} \\
\hline QYM201 & 90 & 0 & 0 & 0 & 0 & 0 & 0 & 0 & 0 & $6136(34)^{\mathrm{b}}$ & $5930(103)^{\mathrm{d}}$ & 9.8 & 11.8 \\
\hline QYM201 & 135 & 0 & 0 & 0 & 0 & 0 & 0 & 0 & 0 & $6321(270)^{\mathrm{ab}}$ & $6099(32)^{\mathrm{bcd}}$ & 13.1 & 15.0 \\
\hline QYM201 & 180 & 0 & 0 & 0 & 0 & 0 & 0 & 0 & 0 & $6411(246)^{\mathrm{ab}}$ & $6231(23)^{\mathrm{bcd}}$ & 14.7 & 17.5 \\
\hline QYM201 & 270 & 0 & 0 & 0 & 0 & 0 & 0 & 0 & 0 & $6529(229)^{\mathrm{ab}}$ & $6311(46)^{\mathrm{ab}}$ & 16.8 & 19.0 \\
\hline Fenoxapro-P-ethyl & 50 & 0 & 0 & 0 & 0 & 0 & 0 & 0 & 0 & $6009(132)^{\mathrm{bc}}$ & $5885(109)^{\mathrm{d}}$ & 7.5 & 10.9 \\
\hline Tribenuron-methyl & 22.5 & 0 & 0 & 0 & 0 & 0 & 0 & 0 & 0 & $6199(36)^{\mathrm{ab}}$ & $6054(39)^{\mathrm{cd}}$ & 10.9 & 14.1 \\
\hline Hand-weeding & - & - & - & - & - & - & - & - & - & $6734(214)^{\mathrm{ab}}$ & $6488(84)^{\mathrm{ab}}$ & 20.5 & 22.3 \\
\hline Weedy control & - & - & - & - & - & - & - & - & - & $5590(250)^{c}$ & $5305(90)^{\mathrm{e}}$ & - & - \\
\hline
\end{tabular}

Table 5. Visual estimates for wheat injury and wheat yields under different POST rates of QYM201 at Tai'an,

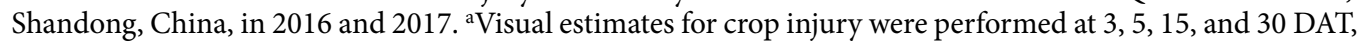
using a $0 \%$ (no crop injury) and $100 \%$ (plant death) scale. ${ }^{b}$ Different significance between the wheat injuries or wheat yields of 2 years according to Fisher's protected LSD test at the 0.05 level. *Significant; NS, not significant. 'The following different letters represent different significance at the $\mathrm{P}<0.05$ level according to Fisher's protected LSD test. 
The 2-year field experiments demonstrated that the herbicide QYM201 had good efficacy against A. aequalis, D. sophia, and M. aquaticum with POST at doses of 90-270 g a.i. ha ${ }^{-1}$. Previous field studies further indicate that QYM201 has potential as a POST for weed control. Cheng et al. ${ }^{35}$ report that weeds die more slowly than in the glasshouse, which was in accordance with our research. This might be owing to greater weed leaf-age and lower temperatures in the field. Furthermore, no obvious damage to wheat plants was observed during the 2 experimental years in any QYM201 treatments. Moreover, the effect of QYM201 on crop yield was characterized; results showed that wheat yields were higher in 2016 than in 2017 (Table 5). The differences between the data received might be owing to the lower weed density occurring in the experimental sites in 2016. Other factors such as different environmental conditions could also have caused these differences. Wheat yield was increased for all the QYM201 treatments; furthermore, the wheat yield at $270 \mathrm{~g}$ a.i. ha ${ }^{-1}$ was not much different from that at $180 \mathrm{~g}$ a.i. $\mathrm{ha}^{-1}$. According to our research, all of the facts indicate that the recommended dosage of QYM201 is 90 to $180 \mathrm{~g}$ a.i.ha ${ }^{-1}$. Field results indicated that the hand-weeding plots had the highest yield among all the treatments; however, the cost of labor make this economically unattractive ${ }^{36,37}$. It is commonly agreed that the combination of chemical measures with other agronomic methods may result in economical and effective control of weeds in wheat fields.

In summary, results from greenhouse and field studies indicated that QYM201 has good potential as an efficient broad-spectrum herbicide for controlling weeds in wheat fields. Under the challenge of controlling multiple herbicide resistance in weeds, the novel structure of this herbicide and its different mode of action could be an ideal option for weed control, especially for resistant weed species in wheat fields.

\section{Methods}

Herbicide used. QYM201 (Kingagroot, Qingdao, China) with 98\% purity and 6\% oil dispersion (OD) was provided by Qingdao Kingagroot Chemicals Co., Ltd. Control herbicides fenoxapro-P-ethyl $69 \mathrm{~g} \mathrm{~L}^{-1}$ and tribenuron-methyl 75\% WDG were provided by Bayer Crop Science Co., Ltd. and Jiangsu Rotam Chemicals Co., Ltd., respectively. To obtain a series of concentrations, QYM201 98\% technical material (TC) was dissolved in ethanol and diluted with $0.1 \%$ Tween-80 solutions. QYM201 6\% OD and the 2 control herbicides were dissolved and diluted with deionized water.

Greenhouse experiment. Weed seeds of A. aequalis, A. japonicus, Veronica didyma Tenore, D. Sophia, and Becmannia syzigachne (Steud.) Fern were collected from Jiangsu province and the other 13 weed species were collected from Henan province, China, in 2014 (Table 1). All weed species seed germination rates were $>85 \%$. All wheat hybrids used in this study can be found in the agricultural seed market and they are listed in Table 2. Germination rates of all wheat seeds were $>80 \%$. All greenhouse conditions involved were similar to those in a previous experiment ${ }^{38}$. Experiments were executed at Shandong Agricultural University, Taian, China. Weed and wheat seeds were immersed in a petri dish containing distilled water and placed in a $12 \mathrm{~h}$ photoperiod and $20^{\circ} \mathrm{C}$ growth chamber (Model RXZ, Ningbojiangnan Instrument Factory, Ningbo, China) to accelerate germination before planting. After visualization of seed radicles, 15-30 seeds were sown below the soil surface per plastic pot $(160 \mathrm{~mm}$ diameter and $130 \mathrm{~mm}$ height). After weed emergence, the seedlings were thinned to 10 plants per plastic pot. At the 3-5 leaf stage the seedlings were treated with QYM201 using an auto spraying tower (Model ASS-4, National Agricultural Information Engineering and Technology Center of China) at a spray pressure of $0.275 \mathrm{MPa}$ with $450 \mathrm{~L} \mathrm{ha}^{-1}$ spray volume. All greenhouse experiments had replications and were repeated once.

Effectiveness of weed control. All 18 tested weed species were treated with QYM201 at dosage rates of 90 and $135 \mathrm{~g}$ a.i. $\mathrm{ha}^{-1}$, and an untreated control was designed for each weed species. After 28 days of treatment, the surviving weeds were cut off at the soil surface and placed in a labeled paper bag, put in an oven at $80^{\circ} \mathrm{C}$ for $72 \mathrm{~h}$, and finally the dry weights were recorded ${ }^{39}$. Other experimental conditions were consistent with those described above for the greenhouse experiment.

Wheat hybrid tolerance. All wheat hybrids were treated with QYM201 at 360 and $540 \mathrm{~g}$ a.i. ha ${ }^{-1}$, and a non-treated control was also designed. After 28 days of treatment, wheat plants were cut off and put in an oven at $80^{\circ} \mathrm{C}$ for $72 \mathrm{~h}$, and then dry weights were recorded. In addition, the degree of herbicide damage to wheat seedlings was also recorded and expressed as values from 0 to $100 \%$ : $0 \%$ indicated no damage and $100 \%$ indicated total death ${ }^{31}$. Other experimental conditions were consistent with those described above for the greenhouse experiment.

Selectivity index (SI). The selectivity index refers to the ratio between the concentrations that caused $10 \%$ growth inhibition of crops and $90 \%$ growth inhibition in weeds $s^{40}$. Three commonly cultivated wheat hybrids [Jimai 22 (JM 22), Liangxing 66 (LX 66), and Tainong 18 (TN 18)] in China and 4 widespread weeds (A. aequalis, A. japonicas, C. bursa-pastoris, and M. aquaticum) that occur in wheat fields were selected for testing. In order to obtain the SI values between wheat and weed species under QYM201 application, JM 22, LX 66, and TN 18 were treated at rates of $0,270,405,607,911,1366,2050$, and $3075 \mathrm{~g}$ a.i. ha ${ }^{-1}$; A. aequalis and M. aquaticum were treated with doses of $0,15,30,45,60$, and $75 \mathrm{~g}$ a.i. $\mathrm{ha}^{-1}$; A. japonicus was sprayed at concentrations of $0,45,60,75,90$, and $135 \mathrm{~g}$ a.i. ha ${ }^{-1}$; and C. bursa-pastoris was treated at rates of $0,15,60,90$, and $135 \mathrm{~g}$ a.i. ha ${ }^{-1}$. These experiments were carried out simultaneously under the same experimental conditions. After 28 days of treatment, to record plant dry weights, shoots were harvested and put in an oven at $80^{\circ} \mathrm{C}$ for $72 \mathrm{~h}$. Other conditions during the experiments were consistent with those described above. 


\begin{tabular}{|l|l|l|c|c|c|c|c|l|}
\hline \multirow{4}{*}{ Month } & \multicolumn{9}{|l|}{ Air temperature $\left({ }^{\circ} \mathrm{C}\right)$} & \multicolumn{3}{l|}{$\begin{array}{l}\text { Total precipitation } \\
(\mathbf{m m})\end{array}$} \\
\cline { 2 - 9 } & Maximum & \multicolumn{2}{|c|}{ Minimum } & \multicolumn{2}{l|}{ Mean } & \\
\cline { 2 - 9 } & $\mathbf{2 0 1 6}$ & $\mathbf{2 0 1 7}$ & $\mathbf{2 0 1 6}$ & $\mathbf{2 0 1 7}$ & $\mathbf{2 0 1 6}$ & $\mathbf{2 0 1 7}$ & $\mathbf{2 0 1 6}$ & $\mathbf{2 0 1 7}$ \\
\hline March & 16.7 & 14.7 & 3.2 & 2.3 & 10.2 & 8.5 & 0 & 15.0 \\
\hline April & 24.1 & 22.5 & 12.2 & 9.5 & 17.7 & 16.0 & 6.9 & 33.3 \\
\hline May & 35.9 & 29.7 & 14.9 & 16.5 & 20.3 & 23.0 & 48.7 & 24.8 \\
\hline June & 30.7 & 30.6 & 20.2 & 19.6 & 25.1 & 24.9 & 167.8 & 62.4 \\
\hline
\end{tabular}

Table 6. Monthly air temperatures and total precipitation at Tai'an experimental site in Shandong, China, during the period from QYM201 application to wheat harvest in 2016 and 2017.

Field experiment. Field experiments were conducted in 2016 and 2017 at Ningyang, Tai'an which is situated in the northern winter wheat growing areas. The soil type was loam with $1.79 \%$ organic matter, $\mathrm{pH} 7.5$, and a widely grown wheat hybrid Tainong 18 was tested in this study. On October 2, 2015, and October 9, 2016, winter wheat was mechanically sown in rows at $15 \mathrm{~cm}$ intervals at a seeding rate of $225 \mathrm{~kg} \mathrm{ha}^{-1}$. The weed species that were common in this area during the 2 experimental years were A. aequalis, D. Sophia, and M. aquaticum. The average densities for $A$. aequalis were 20 and 31 plants per $\mathrm{m}^{2}, 18$ and 28 plants per $\mathrm{m}^{2}$ for $D$. sophia, and 12 and 19 plants per $\mathrm{m}^{2}$ for M. aquaticum, respectively, in 2016 and 2017. Before wheat sowing, diammonium phosphate was applied at a ratio of $450 \mathrm{~kg} \mathrm{ha}^{-1}$, and on March 3, 2016, and March 15, 2017 urea fertilizer was applied at a ratio of $375 \mathrm{~kg} \mathrm{ha}^{-1}$ at the wheat turning green stage. The monthly temperatures and precipitation at the site during the experimental period are shown in Table 6.

All treatments were arranged in a randomized complete block design and repeated 4 times. The area of each plot was $20 \mathrm{~m}^{2}$ ( $4 \mathrm{~m}$ wide and $5 \mathrm{~m}$ long). This experiment contained a total of 8 treatments and there were 4 application rates of QYM201 $\left(90,135,180\right.$, and $270 \mathrm{~g}$ a.i. ha ${ }^{-1}$ ); a single concentration of fenoxapro-P-ethyl (at a rate of $50 \mathrm{~g}$ a.i. $\mathrm{ha}^{-1}$ ) and tribenuron-methyl (at a dose of $25 \mathrm{~g}$ a.i. ha ${ }^{-1}$ ), respectively; a hand-weeded control (using hand hoes at 0, 15, 30 and 45 DAT) and an untreated control (Table 4). On March 21, 2016, and March 16, 2017, weeds were sprayed with herbicides at the 7 to 8 leaf stage. The average temperatures on the days of application were $13.2^{\circ} \mathrm{C}$ and $9.7^{\circ} \mathrm{C}$, respectively. Herbicides were applied using a backpack sprayer (Bellspray Inc., Opelousa, LA) fitted with a single 8002 VS nozzle (Teejet Technologies, Wheaton, IL) in $450 \mathrm{~L} \mathrm{ha}^{-1}$ of water.

Visual estimates for crop injury were performed at 3, 5, 15, and 30 DAT, using a $0 \%$ (no crop injury) and $100 \%$ (plant death) scale. Visual estimates for weed control were recorded after 45 days of treatment, using a $0 \%$ (no weed control) to $100 \%$ (complete weed control) scale ${ }^{30}$. In each test plot a random sample area of $0.33 \mathrm{~m}^{2}$ was surveyed at 3 sample points. The number of healthy plants of 3 weed species at each sample point was investigated at $0,15,30$, and $45 \mathrm{DAT}$, and the fresh weight of weeds was recorded while investigating the number of weeds at 45 DAT. At the time of wheat harvesting, 3 samples were taken per plot and weighed to evaluate the grain yield of each plot; the resulting wheat yield was expressed as $\mathrm{kg} / \mathrm{ha}$.

Statistical analysis. All greenhouse experiment data were subjected to Analysis of Variance (hereafter referred to as ANOVA; Version 22.0; IBM Corporation, Armonk, NY). Data were pooled because there was no significant $(\mathrm{P}>0.05)$ interaction with the 2 replicate treatments, and means were separated using Fisher's protected LSD tests at the 0.05 level. All regression analyses were performed using SigmaPlot software (Version 13.0; Systat Software Inc., CA, USA). To evaluate weed control and assess the dose of QYM201 required for 90\% weed control, regression of weed dry matter over herbicide dose was performed using the 4 parameter log-logistic model described by Seefeldt et al. ${ }^{41}$ :

$$
y=c+(d-c) /\left\{1+\exp \left[b\left(\log x-\log G R_{50}\right)\right]\right\}
$$

where $b$ is the slope of the line, $c$ is the lower limit, $d$ is the upper limit. $x$ is the herbicide dose, $G R_{50}$ is the dose giving $50 \%$ response, and $y$ is the growth response (percentage of the untreated control).

$G R_{10}, G R_{50}$, and $G R_{90}$ values were calculated according to regression parameters ${ }^{18}$. The SI values of QYM201 were calculated by the following equation:

$$
S I_{(10,90)}=G R_{10(\text { crop })} / G R_{90(\text { weed })}
$$

where $G R_{10}$ is the dose of wheat growth reduction by $10 \%$, and $G R_{90}$ is the dose of weeds growth reduction by $90 \%$.

Field experiment data were subjected to ANOVA, and means were separated using Fisher's protected LSD tests at the 0.05 level. Treatment interactions of the 2 years were not significant $(\mathrm{P}>0.05)$, therefore the data were pooled by the year.

\section{Data Availability}

All data generated or analyzed in this study are included in the Supplementary Information files.

\section{References}

1. NBSC (National Bureau of Statistics of China). National data. http://data.stats.gov.cn/easyquery.htm? $\mathrm{cn}=\mathrm{C} 01$, Accessed date: 31 January 2017 (2017).

2. Zhang, C. et al. Current advances in research on herbicide resistance. Scientia Agricultura Sinica 42, 1274-1289 (2009). 
3. Tu, H. L. The succession of weed population in five crops in Sustainable weed management in the 21st Century (ed. Sun, D. C.) 5-9 (Guangxi Nationality Press, 1999).

4. Zhang, Z. P. Development of chemical weed control and integrated weed management in China. Weed Biol. Manag. 3, 197-203 (2003).

5. Su, S. New herbicides, formulation and combination product. Modern Agrochemicals 6, 1 (2007).

6. Baghestani, M. A., Zand, E., Soufizadeh, S. \& Rahimian, M. H. Morphological and physiological characteristics which enhance competitiveness of winter wheat (Triticum aestivum) against Goldbachia laevigata. Iranian J. Weed Sci. 1, 111-126 (2005).

7. Délye, C., Jasieniuk, M. \& Le Corre, V. Deciphering the evolution of herbicide resistance in weeds. Trends Genet. 29, 649-658 (2013).

8. Mallory-Smith, C. A. \& Retzinger, E. J. Revised classification of herbicides by site of action for weed resistance management strategies. Weed Technol. 17, 605-619 (2003).

9. Wakabayashi, K. \& Böger, P. Target sites for herbicides: entering the 21st century. Pest Manag. Sci. 58, 1149-1154 (2002).

10. Heap, I. International survey of herbicide resistant weeds. http://www.weedscience.com, Accessed date: 31 January 2017 (2017).

11. Zhu, J. et al. Weed research status, challenges, and opportunities in China. Crop Protection., https://doi.org/10.1016/j.cropro.2018. $02.001(2018)$

12. Feng, Y. J., Gao, Y., Zhang, Y., Dong, L. Y. \& Li, J. Mechanisms of resistance to pyroxsulam and ACCase inhibitors in Japanese Foxtail (Alopecurus japonicus). Weed Sci. 64, 695-704 (2016).

13. Li, X., Li, B., Su, L. \& Suo, Z. Study on weed control efficacy and wheat injures of 2, 4-D butylate. J. Hebei Agric. Sci. 6, 1-4 (2002).

14. Zhang, C. X., He, X. G. \& Li, H. B. Drift injury of 2, 4-D butyl ester and remedial measures to cotton. Hubei Plant Prot. 1, 35-36 (2005).

15. Anonymous. KingAgroot. http://www.kingagroot.com/product_sanzuo.html (2017).

16. Pallett, K. E. The mode of action of isoxaflutole: a case study of an emerging target site in Herbicides and their mechanisms of action (eds. Cobb, A. H. \& Kirkwood, R. C.) 215-238 (Sheffield Academic, 2000).

17. Hirai, K., Uchida, A. \& Ohno, R. Major synthetic routes for modern herbicide classes and agrochemical characteristics in Herbicide classes in development: mode of action, targets, genetic engineering, chemistry (eds Böger, P., Wakabayashi, K. \& Hirai, K.) 179-289 (Springer, 2002).

18. Matringe, M., Sailland, A., Pelissier, B., Rolland, A. \& Zink, O. p-Hydroxyphenylpyruvate dioxygenase inhibitor-resistant plants. Pest Manag. Sci. 61, 269-276 (2005).

19. Mitchell, G. et al. Mesotrione: a new selective herbicide for use in maize. Pest Manag. Sci. 57, 120-128 (2001).

20. Norris, S. R., Barrette, T. R. \& DellaPenna, D. Genetic dissection of carotenoid synthesis in arabidopsis defines plastoquinone as an essential component of phytoene desaturation. Plant Cell 7, 2139-2149 (1995).

21. Boger, P. Carotenoid biosynthesis inhibitor herbicides-mode of action and resistance mechanism. Pesticide Outlook 9, 29-35 (1998).

22. Schönhammer, A., Freitag, J. \& Koch, H. Topramezone - ein neuer Herbizidwirkstoff zur hochselektiven Hirse- und Unkrautbekämpfung in Mais [Topramazone - A new highly selective herbicide compound for control of warm season grasses and dicotyledoneous weeds in maize]. J. Plant Diseas. Proct. (Suppl. 20), 1023-1031 (2006).

23. Yang, G. Q. et al. Efficacy experiment on several kinds of broadleaf herbicide in wheat field. Beijing Agric 21, 41-42 (2009).

24. ICAMA (Institute for Control of Agrichemicals, Ministry of Agriculture). The Bulletins of the Pesticide Registration in China. China Agriculture Press, Beijing, China. p. 166 (1988).

25. Guo, W. et al. Fenoxaprop-P-ethyl and mesosulfuron-methyl resistance status of shortawn foxtail (Alopecurus aequalis Sobol.) in eastern China. Pestic. Biochem. Physiol. 148, 126-132 (2018).

26. Guo, W. et al. Multiple resistance to ACCase and AHAS-inhibiting herbicides in shortawn foxtail (Alopecurus aequalis Sobol.) from China. Pestic. Biochem. Physiol. 124, 66-72 (2015).

27. Xia, W. et al. Molecular basis of ALS- and/or ACCase-inhibitor resistance in shortawn foxtail (Alopecurus aequalis Sobol.). Pestic. Biochem. Physiol. 122, 76-80 (2015).

28. Li, Y. et al. Studies on resistance of weeds Backmannia Syzigachne and Alopecurus japonicum to herbicide chlorsulfuron. Jiangsu Journal of Agricultural Sciences 12, 34-38 (1996).

29. Li, Y., Wu, J., Wang, Q. \& Liu, L. Resistance of Alopecurus japonicum on chlorsulfuron, isoproturon and fenoxaprop-p-ethyl. Jiangsu Journal of Agricultural Science 21, 293-287 (2005).

30. Mohamed, I. A., Li, R., You, Z. \& Li, Z. Japanese foxtail (Alopecurus japonicus) resistance to fenoxaprop and pinoxaden in China. Weed Sci. 60, 167-171 (2012).

31. Cong, C. et al. Evaluation of weed efficacy and crop safety of fluorochloridone in China. Weed Technol. 28, 721-728 (2014).

32. Beckie, H. J. \& Harker, K. N. Our top 10 herbicide-resistant weed management practices. Pest Manag. Sci. 73, 1045-1052 (2017).

33. Tind, T., Mathiesen, T. J., Jensen, J. E., Ritz, C. \& Streibig, J. C. Using a selectivity index to evaluate logarithmic spraying in grass seed crops. Pest Manag. Sci. 65, 1257-1262 (2009).

34. Bartley, M. R. Assessment of herbicide selectivity in Herbicide bioassays (eds. Streibig, J. C. \& Kudsk, P.) 57-74 (CRC Press, 1993).

35. Cheng, X. et al. Weed control efficacy and winter wheat safety of a novel herbicide HW02. Crop Prot. 43, 246-250 (2013).

36. Gianessi, L. P. The increasing importance of herbicides in worldwide crop production. Pest Manag. Sci. 69, 1099-1105 (2013).

37. Mulder, T. A. \& Doll, J. D. Integrating reduced herbicide use with mechanical weeding in corn (Zea mays). Weed Technol. 7, 382-389 (1993).

38. Zhao, N. et al. Greenhouse and field evaluation of isoxaflutole for weed control in maize in China. Scientific Reports. 7, 12690 (2017).

39. Yuan, G. et al. Molecular basis for resistance to ACCase-inhibiting herbicides in Pseudosclerochloa kengiana populations. Pestic. Biochem. Physiol. 119, 9-15 (2015).

40. Grossmann, K. \& Ehrhardt, T. On the mechanism of action and selectivity of the corn herbicide topramezone: a new inhibitor of 4-hydroxyphenylpyruvate dioxygenase. Pest Manag. Sci. 63, 429-439 (2007).

41. Seefeldt, S. S., Jensen, J. E. \& Fuerst, E. P. Log-logistic analysis of herbicide dose-response relationships. Weed Technol. 9, 218-227 (1995).

\section{Acknowledgements}

This work was supported by the National Key R\& D Program of China (2016YFD0300709, 2016YFD0300701), the Special Fund for Agroscientific Research in the Public Interest (No. 201303031), and the Funds of "Shandong Double" Tops Program (No. SYL2017XTTD11). All authors thank Qingdao Kingagroot Chemicals Co., Ltd. for providing the QYM201 herbicide used in this study. The authors are also grateful for the professional English language editing services of American Journal Experts (Certificate Verification Key: 9511-01E9-81794BBC-0E45).

\section{Author Contributions}

F.Z., H.W. and J.W. designed and performed the greenhouse studies. F.Z. performed the field experiments and data analysis. F.Z. and W.L. wrote the paper. All authors edited and reviewed the manuscript. 


\section{Additional Information}

Competing Interests: The authors declare no competing interests.

Publisher's note: Springer Nature remains neutral with regard to jurisdictional claims in published maps and institutional affiliations.

(c) (i) Open Access This article is licensed under a Creative Commons Attribution 4.0 International License, which permits use, sharing, adaptation, distribution and reproduction in any medium or format, as long as you give appropriate credit to the original author(s) and the source, provide a link to the Creative Commons license, and indicate if changes were made. The images or other third party material in this article are included in the article's Creative Commons license, unless indicated otherwise in a credit line to the material. If material is not included in the article's Creative Commons license and your intended use is not permitted by statutory regulation or exceeds the permitted use, you will need to obtain permission directly from the copyright holder. To view a copy of this license, visit http://creativecommons.org/licenses/by/4.0/.

(c) The Author(s) 2019 